\title{
Physico-chemical and sensory evaluation of virgin olive oils from several Algerian olive-growing regions
}

\author{
Malika Douzane ${ }^{1}$, Mohamed-Seghir Daas ${ }^{1}$, Amel Meribai ${ }^{2}$, Ahmed-Hani Guezil $^{2}$ (D), Abdelkrim Abdi $^{1}$ \\ and Abderezak Tamendjari ${ }^{3, *}$ (I) \\ ${ }^{1}$ Agri-Food Technologies Research Division, National Institute of the Agronomic Research of Algeria (INRAA), El Harrach, Algiers, Algeria \\ 2 Faculty of Mechanical Engineering and Process Engineering, University of Science and Technology Houari Boumediene of Algiers \\ (USTHB), Bab Ezouar, Algiers, Algeria \\ ${ }^{3}$ Laboratory of Applied Biochemistry, Faculty of Natural and Life Sciences, University of Bejaia, Bejaia, Algeria
}

Received 26 June 2021 - Accepted 14 November 2021

\begin{abstract}
Olive cultivar diversity is rich in Algeria but most remain unexplored in terms of quality traits. This work aimed to evaluate the physicochemical and organoleptic quality of twenty olive oil samples belonging to four Algerian cultivars (Chemlal, Sigoise, Ronde de Miliana and Rougette de Mitidja) collected throughout the national territory. Physical-chemical and sensory results showed that $60 \%$ of the oils belong to the extra virgin category, while $40 \%$ were classified as "virgin olive oil". The results of the principal component analysis (PCA) revealed a great variability in fatty acids composition between the samples depending on the cultivar and origin. Oleic acid was the most abundant and varied between 64.84 and $80.14 \%$. Extra virgin olive oils with quality attributes are eligible for a label. Rougette de Mitidja, Ronde de Miliana and Sigoise from Oran showed great potential.
\end{abstract}

Keywords: Algerian cultivars / olive oil / chemical composition / sensory analyses / principal component analysis

Résumé - Évaluation physico-chimique et sensorielle des huiles d'olive vierges de plusieurs régions oléicoles algériennes. La diversité des cultivars d'olives est riche en Algérie mais la plupart restent inexplorées en termes de caractères de qualité. Ce travail vise à évaluer la qualité physico-chimique et organoleptique d'une vingtaine d'échantillons d'huile d'olive appartenant à quatre cultivars algériens (Chemlal, Sigoise, Ronde de Miliana et Rougette de Mitidja) collectés sur l'ensemble du territoire national. Les résultats physico-chimiques et sensoriels ont montré que $60 \%$ des huiles appartiennent à la catégorie extra vierge, tandis que $40 \%$ ont été classées comme «huile d'olive vierge ». Les résultats de l'analyse en composantes principales $(\mathrm{ACP})$ ont révélé une grande variabilité de la composition en acides gras entre les échantillons en fonction de la variété et de l'origine. L'acide oléique est le plus abondant et variait entre 64,84 et $80,14 \%$. Les huiles d'olive extra vierge avec des attributs de qualité sont éligibles à un label. Rougette de Mitidja, Ronde de Miliana et Sigoise d'Oran ont montré un bon potentiel.

Mots clés : Cultivars algériens / huile d'olive / composition chimique / analyse sensorielle / analyse en composantes principales

\section{Introduction}

\section{Highlight}

- Quality of twenty olive oil belonging to four cultivars from different regions was studied.

- Physical-chemical and sensory results showed that $60 \%$ of the oils belong to the extra virgin category.

- Variability in fatty acids composition depends on the cultivar and origin.

- Some secondary cultivars showed a great potential.

*Correspondence: abderezakt@yahoo.fr
The olive tree (Olea europaea L.) is one of the most prominent fruit trees in Mediterranean countries, accounting for $97.9 \%$ of the total area of olive trees in the world (Rallo et al., 2018). More than 11 million ha of olive trees are grown in more than 47 countries, mainly in Spain (25\%), Tunisia $(13 \%)$, Italy (11\%), Morocco $(10 \%)$ and Greece $(9 \%)$ (FAOSTAT, 2018). Algeria is one of the main producers of olives; olive trees have been ranked as the first fruit tree (Algerian Ministry of Agriculture). The area covered by olive trees has increased from 310644 ha in 2010 (M.A.D.R, 2010) to 500000 ha, in 2018 (M.A.D.R.P, 2018). The olive oil sector 
is increasingly considered as economic and social development of diverse regions, including Kabylia and Oranía. During the 2017/2018 campaign, Algeria produced 80000 tons, ranking at the ninth position worldwide.

Virgin olive oil (VOO) extracted from fresh and undamaged fruits (Olea europaea L.), and appropriately processed, is a staple of the Mediterranean diet (Bedbabis et al., 2010). Olive oil is widely appreciated by consumers (Caporale et al., 2006) for its sensory properties (Angerosa et al., 2004; Bendini et al., 2007), nutritional and health benefits (Visioli and Galli, 1998). Several studies have highlighted the effectiveness of the bioactive compounds from olive oil in curing and prevention various chronic diseases, such as atherosclerosis, diabetes, cancer, neurodegenerative, and coronary heart diseases (Lou-Bonafonte et al., 2012; Visioli et al., 2018).

Olive oil quality is referred to international standards defined by several organizations (European Commission Regulation, 2016; Codex Alimentarius, 2017; IOC, 2018c; Conte et al., 2020). Olive oil quality assessment was performed by physicochemical parameters, including free acidity content, peroxide value, specific UV spectrophotometric absorptions $\left(\mathrm{K}_{232}\right.$ and $\left.\mathrm{K}_{270}\right)$, and sensory evaluation (Gharbi et al., 2015).

The olive oil quality, nutritional and sensory characteristics are associated with the chemical composition, which is the result of a complex interaction between several environmental, agronomic, and technological factors (El Riachy et al., 2018). The cultivar, growing area, environmental conditions, soil, tree age, irrigation, fruit ripening, harvest time, fruit storage and processing system represent the important factors influencing the composition of olive oil (Gharbi et al., 2015; Ben Rached et al., 2017; Mele et al., 2018; Faci et al., 2021).

Algeria has an important potential to develop olive oil production, which could place it among the main producing and exporting countries. The quality of olive oil has not been consistently a priority, with only $15 \%$ of the quantity produced belonging to the category of virgin and extra virgin oils. Currently, there is a renewed interest in the production of quality olive oil.

The enhancement and improvement of olive oil require the study of its quality and chemical composition which must comply with international standards. This work has aimed to assess the quality of Algerian olive oil according to the cultivar and area of cultivation to valorize the best ones.

\section{Materials and methods}

\subsection{Plant material and sampling}

The present work was carried on four cultivars of the local population, namely Chemlal, Sigoise, Ronde de Miliana and Rougette de Mitidja from different olive-growing regions of the country. Chemlal is the most widely grown cultivar in Algeria; it represents $40 \%$ of the Algerian olive grove. The fruits are small (about $1.7 \mathrm{~g}$ ) and used for oil production; the oil yield varies between 14 and $22 \%$. Sigoise occupies $25 \%$ of the Algerian olive grove and is located in the west plains. This cultivar is mainly used for the production of table olives which is characterized by medium-sized fruits $(3.5 \mathrm{~g})$. Ronde de Miliana occupies a limited olive-growing area. It is a dual-use cultivar (table olive and olive oil). The oil yield is estimated between 16 and $20 \%$. Rougette de Mitidja is a cultivar intended for the production of oil with a yield varying from $18-20 \%$.

The olive oil samples (twenty) produced during the 2018 2019 olive-growing season was collected from various producers during the months of November-December 2018.

Origin of the plant material and some agronomical conditions of each geographical area were shown in Table 1 and Figure 1. The olive trees have not undergone any chemical treatment.

Extraction of olive oil was performed immediately after harvest. The quantity of olives used for extraction is equal to or greater than $300 \mathrm{~kg}$. The modern (automatic) three-phase system with a hammer crusher, malaxer and centrifugation of the olive paste is used for the extraction of the oil. All samples were packed in amber glass bottles without headspace and stored at $4{ }^{\circ} \mathrm{C}$ until analysis. Different analyses were performed during the first ten of the month of January 2019 for all the samples.

\subsection{Quality and physical indices}

Free acidity (IOC, 2015a), peroxide value (IOC, 2016), and UV spectrophotometric indices $\left(\mathrm{K}_{232}, \mathrm{~K}_{270}\right)$ (IOC, 2015b) were determined. Physical characteristics as refraction index $\left({ }^{\mathrm{n}} \mathrm{D}^{20}\right)$ (ISO, 2006), density (IUPAC, 1987), water content, and volatile matter (ISO, 2016) were also determined.

\subsection{Sensory analysis}

A sensory analysis (median of defects, median of fruitiness, and panel classification test) of the samples was performed by 10 selected and trained panelists (IOC certified panel leader). The profile sheet was used according to the IOC Mario Solinas competition for extra virgin olive oils (T.30/ Doc. No.21, March 2018). The strengths of the positive (fruity, bitter, and pungent) and negative (fusty, winy, musty, muddy, rancid, metallic, and others) attributes were evaluated for each oil sample on a 10 scale. The sensorial evaluation results were estimated by the median, being valid when the coefficient of variation was less than 20 (IOC/T.20/Doc. No.15/Rev.10, 2018).

\subsection{Colorimetric determination of total phenols}

The total phenol content of the olive oil samples was determined by the Folin-Ciocalteu spectrophotometric method at $725 \mathrm{~nm}$, using a gallic acid calibration curve (Gutfinger, 1981).

\subsection{Fatty acid composition}

The fatty acid composition of the oils was determined by gas chromatography (GC) as fatty acid methyl esters (FAMEs). FAMEs were prepared by cold transesterification with methanolic solution of potassium hydroxide (2N) according the method of European Commission implementing Regulation 2015/1833 amending Regulation (EEC) No. 2568/91. The solution containing the fatty acid methyl esters was injected in 


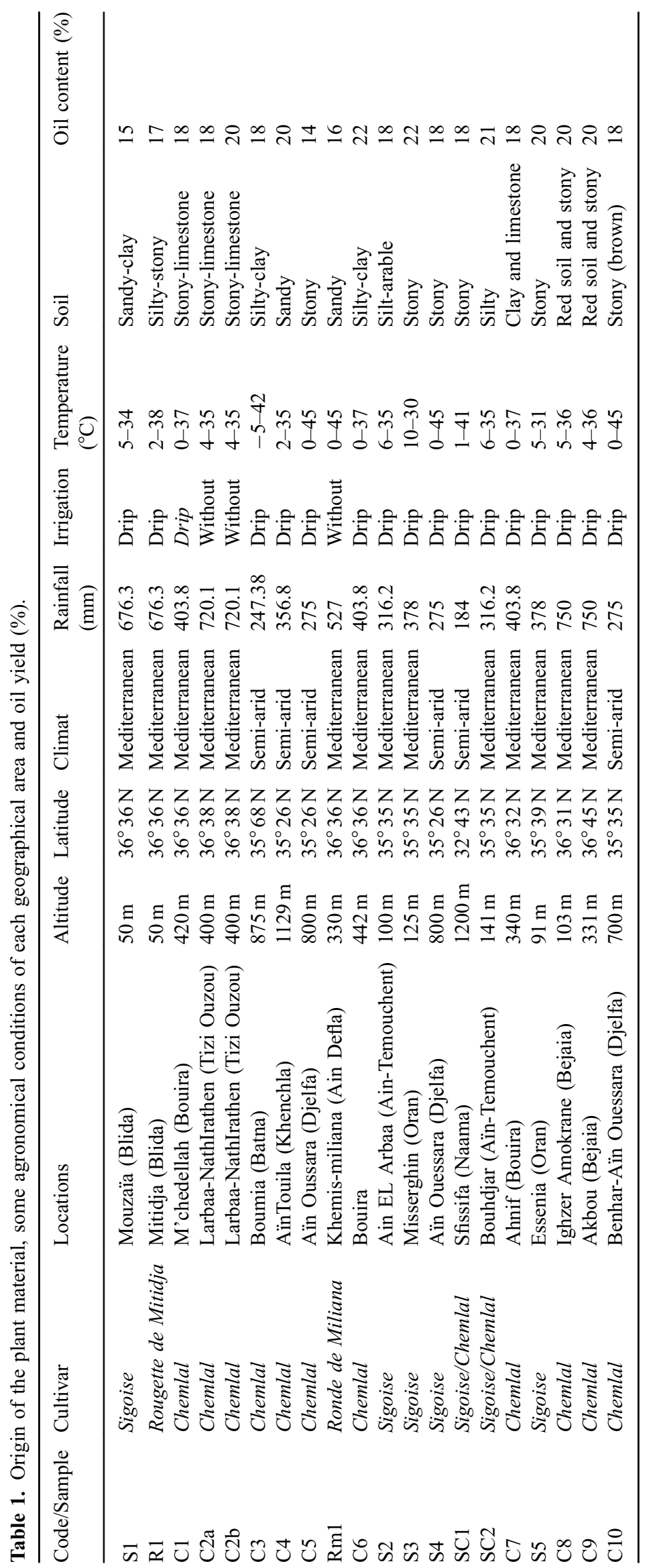

Page 3 of 11 


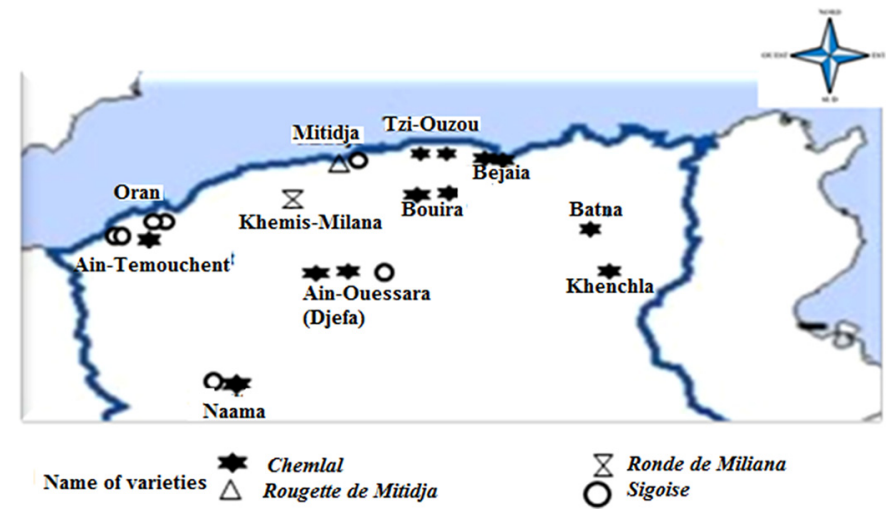

Fig. 1. Geographic origin and varieties of olive oil samples collected in Algeria.

split mode. Aanalysis was performed in a Chrompack CP 9002, equipped with a flame ionization detector (FID). An agilent capillary column (DB 23, $60 \mathrm{~m}$ length, $0.25 \mathrm{~mm}$ i.d, $0.25 \mu \mathrm{m}$ film thickness), (Cyanopropyl at 50\%) (USA) was used. The column temperature was isothermal at $200{ }^{\circ} \mathrm{C}$ and the injector and detector temperatures were $250{ }^{\circ} \mathrm{C}$. Nitrogen as a carrier gas was used at flow rates of $1 \mathrm{~mL} / \mathrm{min}$. Fatty acids were identified by comparison of their retention times with those of standard reference compounds. Analyses were performed in duplicate.

\subsection{Statistical analysis}

All analyses were performed in triplicate, except for fatty acid composition, which is performed in duplicate; the results are presented as mean values. A simple analysis of variance was conducted according to the LSD test at the 5\% threshold with GenStat Discovery Edition software. $\mathrm{P} \geq 0.05$ indicates that the effect is considered non-significant.

The correlation between the different analytical parameters is treated by principal component analysis (PCA), to highlight associations of individuals or links between variables. The data were statistically processed by the Statistica software version 12.5 .

\section{Results and discussion}

\subsection{Oil content}

The oil yield of the olives from the different samples is shown in Table 1. There are differences between the oil contents of the different cultivars. Chemlal from Djelfa (C5) has the lowest percentage (14\%) and Sigoise from Oran (S3) has the highest percentage (22\%). Al-Ruqaie et al. (2016) and Giuffrè (2017) showed that the cultivar significantly influences the oil content when samples come from the same harvest area.

The geographic origin of the samples also affects the oil content. For the same Chemlal cultivar, the yield varies from $14 \%$ for the sample from Djelfa (C5) to $22 \%$ for the sample from Bouira (C6). The same observation is noted for the cultivar Sigoise, whose yield varies from 15\% (S1 from Blida) to $22 \%$ (S3 from Oran). The results are in agreement with those of Navas-López et al. (2020) who noted that genotype, environment and their interaction significantly affect the amount of oil.

\subsection{Quality parameters}

The parameters of the studied olive oils (Tab. 2) were within the limits of the European Commission implementing Regulation 2016/1227 amending Regulation (EEC) No. 2568/91 and IOC (2018b) and therefore the oils could be classified into the category of extra virgin olive oil, except samples of Chemlal from Tizi Ouzou (C2a and C2b), Sigoise from Ain-Temouchent (S2) and Djelfa (S4).

The region and cultivar had a highly significant effect $(\mathrm{P} \leq 0.001)$ on the free acidity, the peroxide index, the $\mathrm{K}_{270}$, the water content, and significant effect $(\mathrm{P} \leq 0.01)$ on the $\mathrm{K}_{232}$. Large variations in qualitative indexes according to the cultivar have shown by Piscopo et al., 2016). Significant differences were observed in most of the quality parameters between the extra virgin olive oil of "Sarlulak" olive cultivar produced in three different locations (Antalya, Karaman, Mersin) in the south region of Turkey (Arslan et al., 2013). The geographic area and environmental factors influence the characteristics of Arbequina oil (Borges et al., 2017).

\subsection{Physical indices}

The physical characteristics of all samples are presented in Table 2. The refractive index increases with the degree of unsaturation of the fatty acids. Indeed samples with higher unsaturation showed a higher refractive index. Our results are within the limits [1.468-1.470] set by Codex Alimentarius (2017) standards for extra virgin oils.

Density (MV) depends on the chemical composition of the oil and temperature. Therefore, our results are in the range [0.910-0.916] of Codex Alimentarius (2017). A highly significant difference between the different samples studied $(\mathrm{P} \leq 0.001)$ according to refractive index and density.

\subsection{Sensory analysis}

The flavor and taste of olive oil are strongly correlated with its quality level and nutritional value. Sensory analysis of olive oils, based on median values of the positive and negative attributes carried out by a panel of trained tasters, is one of the most important evaluations used for virgin olive oil quality classification (Fernandes et al., 2018). First, sensorial features of olive oils were analyzed and the oils with defects were discarded. Twelve samples belonging to the extra virgin olive oil category were selected for sensory analyses (Tab. 3).

The results of the organoleptic analysis of the extra virgin oils, presented in Table 4, showed great diversity in its sensorial profiles. The variation in bitterness intensity ranging from 1 to 2.5 and pungency from 1 to 2.5. These attributes are scored on a scale of 1 to 3 . The type of green fruitiness was the same for the different oils, but it was nuanced by the intensity which varies from 6 to 9 .

The results (Tabs. 3 and 4) indicated that the organoleptic note varies from one cultivar to another; the oils of the Sigoise cultivar from Blida (S1) and Aïn-Temouchent (S2) were 
M. Douzane et al.: OCL 2021, 28, 55

Table 2. Analytical characteristics of Algerian extra virgin olive oils at different olive growing region.

\begin{tabular}{|c|c|c|c|c|c|c|c|c|}
\hline Sample & $\begin{array}{l}\text { Free acidity } \\
(\%)\end{array}$ & $\begin{array}{l}\text { Peroxide value } \\
\left(\text { meq } \mathrm{O}_{2} / \mathrm{kg}\right)\end{array}$ & $\mathrm{K}_{232}$ & $\mathrm{~K}_{270}$ & $\mathrm{H} \%$ & ${ }^{n} D^{20}$ & Density & $\begin{array}{l}\text { Total phenols } \\
(\mathrm{mg} / \mathrm{kg})\end{array}$ \\
\hline S1 & $0.22 \pm 0.01$ & $5 \pm 0.11$ & $2.03 \pm 0.02$ & $0.17 \pm 0.01$ & $0.14 \pm 0.01$ & $1.4689 \pm 0.0$ & $0.911 \pm 0.01$ & $351.45 \pm 0.11$ \\
\hline $\mathrm{C} 1$ & $0.16 \pm 0.01$ & $4.5 \pm 0.01$ & $1.91 \pm 0.04$ & $0.15 \pm 0.00$ & $0.19 \pm 0.02$ & $1.4686 \pm 0.0$ & $0.913 \pm 0.00$ & $153.66 \pm 0.07$ \\
\hline $\mathrm{C} 2 \mathrm{a}$ & $1.0 \pm 0.0$ & $6 \pm 0.04$ & $1.95 \pm 0.02$ & $0.16 \pm 0.01$ & $0.21 \pm 0.02$ & $1.4681 \pm 0.0$ & $0.911 \pm 0.01$ & $126.87 \pm 0.03$ \\
\hline $\mathrm{C} 4$ & $0.33 \pm 0.01$ & $2.5 \pm 0.13$ & $2.05 \pm 0.01$ & $0.16 \pm 0.00$ & $0.15 \pm 0.01$ & $1.4682 \pm 0.0$ & $0.916 \pm 0.01$ & $154.68 \pm 0.11$ \\
\hline $\mathrm{C} 5$ & $0.22 \pm 0.01$ & $5 \pm 0.01$ & $2.25 \pm 0.02$ & $0.2 \pm 0.001$ & $0.17 \pm 0.01$ & $1.4687 \pm 0.0$ & $0.910 \pm 0.01$ & $196.41 \pm 0.03$ \\
\hline Rm1 & $0.36 \pm 0.00$ & $6 \pm 0.05$ & $2.05 \pm 0.03$ & $0.16 \pm 0.01$ & $0.16 \pm 0.01$ & $1.4682 \pm 0.0$ & $0.912 \pm 0.01$ & $227.10 \pm 0.01$ \\
\hline C6 & $0.16 \pm 0.01$ & $2.50 \pm 0.01$ & $2.12 \pm 0.01$ & $0.17 \pm 0.01$ & $0.19 \pm 0.01$ & $1.4685 \pm 0.0$ & $0.916 \pm 0.01$ & $187.23 \pm 0.0$ \\
\hline $\mathrm{S} 2$ & $0.16 \pm 0.00$ & $3.5 \pm 0.08$ & $1.98 \pm 0.03$ & $0.16 \pm 0.01$ & $0.16 \pm 0.00$ & $1.4689 \pm 0.0$ & $0.916 \pm 0.01$ & $196.08 \pm 0.02$ \\
\hline $\mathrm{C} 7$ & $0.78 \pm 0.01$ & $8 \pm 0.11$ & $1.87 \pm 0.02$ & $0.17 \pm 0.01$ & $0.19 \pm 0.02$ & $1.4680 \pm 0.0$ & $0.911 \pm 0.02$ & $16.44 \pm 0.09$ \\
\hline S5 & $1.0 \pm 0.0$ & $7.5 \pm 0.01$ & $1.91 \pm 0.03$ & $0.15 \pm 0.01$ & $0.20 \pm 0.02$ & $1.4689 \pm 0.0$ & $0.914 \pm 0.02$ & $61.95 \pm 0.07$ \\
\hline $\mathrm{C} 8$ & $0.33 \pm 0.1$ & $7 \pm 0.14$ & $2.24 \pm 0.03$ & $0.18 \pm 0.02$ & $0.19 \pm 0.02$ & $1.4686 \pm 0.0$ & $0.915 \pm 0.02$ & $153.21 \pm 0.02$ \\
\hline C9 & $0.53 \pm 0.01$ & $10 \pm 0.00$ & $2.20 \pm 0.02$ & $0.18 \pm 0.02$ & $0.17 \pm 0.01$ & $1.4686 \pm 0.0$ & $0.912 \pm 0.01$ & $117.12 \pm 0.04$ \\
\hline $\mathrm{C} 10$ & $0.39 \pm 0.01$ & $21.5 \pm 0.0$ & $3.00 \pm 0.00$ & $0.19 \pm 0.02$ & $0.15 \pm 0.00$ & $1.4689 \pm 0.0$ & $0.913 \pm 0.01$ & $28.43 \pm 0.01$ \\
\hline
\end{tabular}

Results are expressed as mean $\pm \mathrm{SD}$ of three sample replicates.

Significance level: ${ }^{* * *} \mathrm{P}<0.001 ;{ }^{*} \mathrm{P}<0.01 ;{ }^{*} \mathrm{P}<0.05$; NS $=$ not significant. Free acidity: $\mathrm{P}<0.001$; Peroxide value: $\mathrm{P}<0.001 ; \mathrm{K} 232$ : $\mathrm{P}<0.05 ; \mathrm{K}_{270}$ : $\mathrm{P}<0.001 ; \mathrm{H} \%: \mathrm{P}<0.001$; Density: $\mathrm{P}<0.001 ;{ }^{\mathrm{n}} \mathrm{D}^{20}: \mathrm{P}<0.001 ; \mathrm{TP}: \mathrm{P}<0.001$.

characterized by a fruity taste and a higher spicy median than other varieties.

The oil of Rougette de Mitidja cultivar from Blida (R1), with a very local diffusion, obtained a high score of 83.0 , the best of all oils. It also showed a remarkable homogeneity as well as balanced attributes of intense fruity (9.0) and spicy (2.0) and bitter (2.0). The olive cultivar has been reported as one of the most crucial factors responsible for olive oil flavor variability (Tura et al., 2008; Mele et al., 2018). It is well established that the organoleptic properties of olive oil, which are strongly correlated to its geographical and varietal origins, are behind its wide commercialization and elevated market value (Rodney et al., 2010; Borges et al., 2017).

Samples of Chemlal cultivar, the most abundant olive cultivar in Algeria (40\%), from different regions showed a remarkable difference in their sensory characteristics; it varies from ripe fruity with spicy and slightly bitter traits to medium green fruity with more pronounced fruit intensity, stronger spicy and bitter attributes. The same observation was noted for samples from the Sigoise cultivar where the oils have different sensory characteristics.

The cultivar factor has a very significant effect on sensory attributes. The aromatic notes depend on the volatile and phenolic compounds. The volatile composition of olive oil depends on several factors, such as the levels and activity of enzymes involved in different pathways (Angerosa, 2002).
Table 3. Results of the selective classification of the several oils.

\begin{tabular}{ll}
\hline Sample & Comment/Class \\
\hline C2a & Defective oil \\
C2b & Defective oil \\
C4 & Rancid oil \\
C6 & Musty oil \\
S3 & Highly defective oil \\
S4 & Defective oil \\
S5 & Fusty oil \\
C10 & Fusty and musty oil \\
S1 & Medium green fruity \\
R1 & Intense green fruity \\
C1 & Ripe fruity \\
C3 & Ripe fruity \\
C5 & Medium green fruity \\
Rm1 & Medium green fruity \\
S2 & Intense green fruity \\
SC1 & Light green fruity \\
SC2 & Ripe fruity \\
C7 & Light green fruity \\
C8 & Medium green fruity \\
C9 & Medium green fruity \\
\hline
\end{tabular}


M. Douzane et al.: OCL 2021, 28, 55

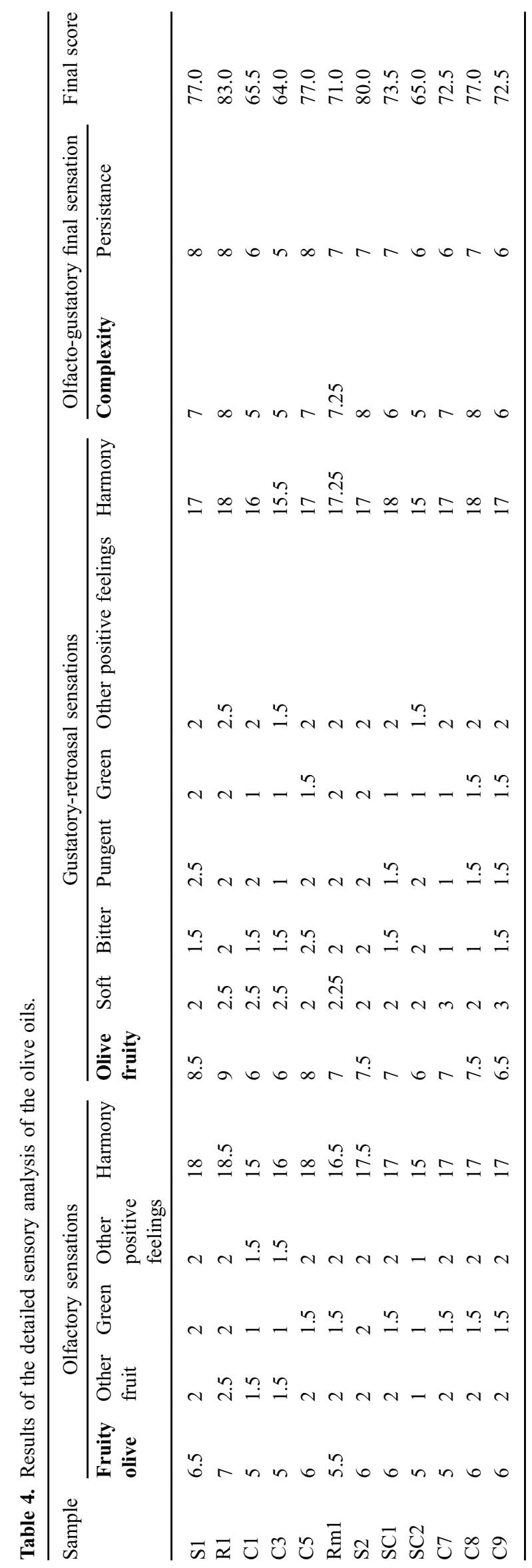

Page 6 of 11 


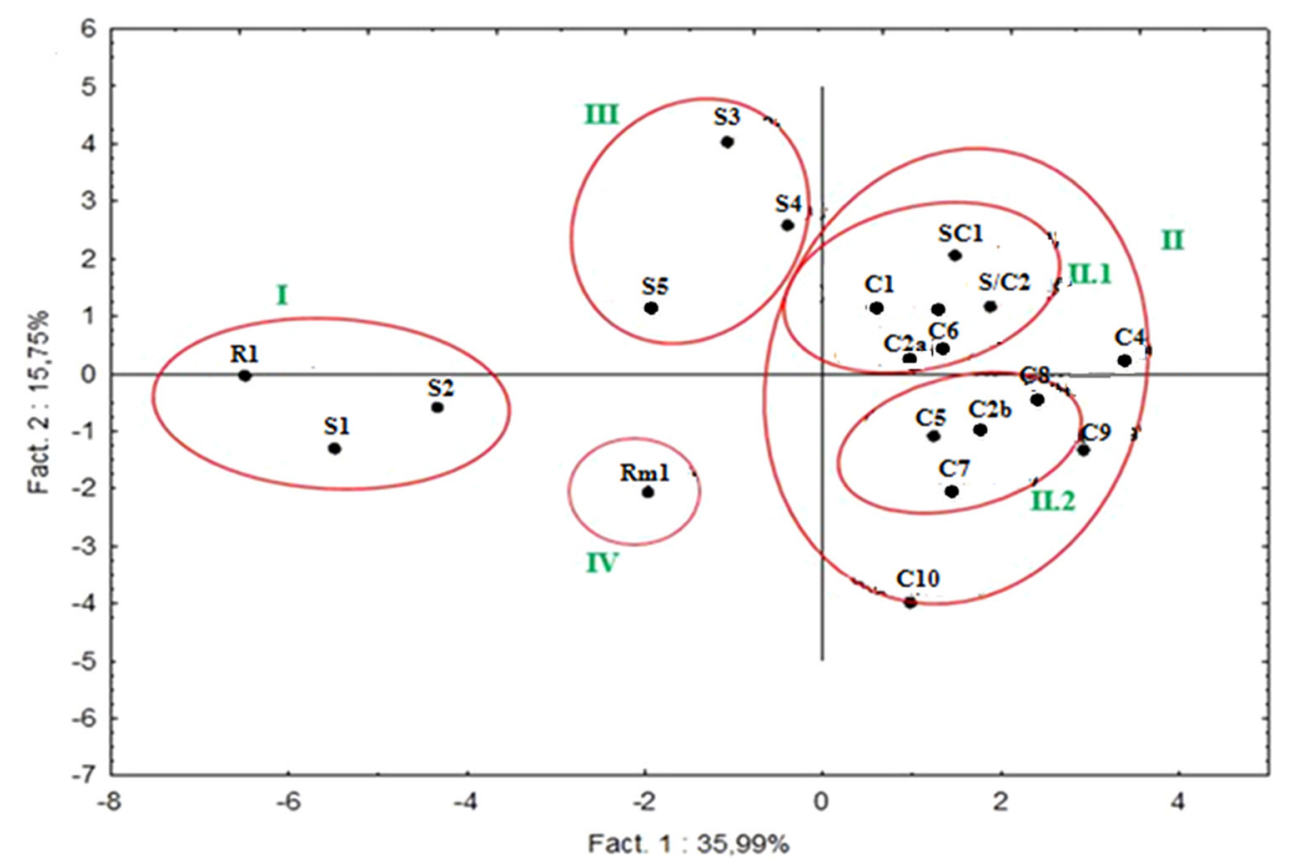

Fig. 2. Projection of the individuals according to the different principal components as plane of projection of the axis 1-2.

The name of samples is indicated by abbreviation (R: Rougette de Mitidja; S: Sigoise; C: Chemlal; Rm: Ronde de Miliana) and number (indicate origin). S1: Sigoise (Mouzaia, Blida); R1: Rougette of Mitidja (Blida); C1: Chemlal (M'chedellah, Bouira); C2a: Chemlal (LarbaaNath Irathen, Tizi Ouzou); C2b: Chemlal (Larbaa-Nath Irathen, Tizi Ouzou); C3: Chemlal (Boumia, Batna); C4: Chemlal (Aïn Touila, Khenchla); C5: Chemlal (Aïn Ouessara, Djelfa); Rm1: Ronde of Miliana (Khemis-Miliana, Ain Defla); C6: Chemlal (Bouira); S2: Sigoise (Ain EL Araba, Ain-Temouchent); S3: Sigoise (Misserghin, Oran); S4: Sigoise (Aïn-Ouessara, Djelfa); SC1:Sigoise/Chemlal (Sfissifa, Naama); SC2: Sigoise/Chemlal (Hammam Bouhdjar, Ain-Temouchent); C7: Chemlal (Ahnif, Bouira); S5: Sigoise (Essenia, Oran); C8: Chemlal (Ighzer Amokrane, Bejaia); C9: Chemlal (Akbou, Bejaia); C10: (Benhar Aïn-Ouessara, Djelfa).

\subsection{Total phenols}

The quality of olive oil is significantly related to polyphenols content (Benlemlih and Ghanam, 2016). The total phenol content of the olive oil ranged from 46.29 to $351.45 \mathrm{mg} / \mathrm{kg}$ (Tab. 2). A high significant difference $(\mathrm{P}<0.001)$ between the different samples from different regions and varieties was noted. These results are lower than those recorded on extra virgin olive oil of Algerian varieties (Douzane et al., 2013).

These low concentrations could be attributed to the olive oil extraction process in which most mills use the conventional three-phase centrifuge where a quantity of water has been added during the extraction process which has led to losses of phenolic compounds, vitamins, and aromatic components. It was reported that the two-phase decanter provides an oil rich in total polyphenols, ortho-diphenols, lower acidity, and better organoleptic quality compared to the three-phase press (Del Caro et al., 2006). Besides the cultivar, the degrees of ripening of the olives and the environmental conditions influence the concentration of phenolic compounds (Škevin et al., 2003). A negative correlation $(\mathrm{r}=-0.88)$ between drupe ripening degree and phenolic content of VOOs was found (Rotondi et al., 2004).

According to Borges et al. (2017), significant variations $(\mathrm{P}<0.05)$ in the concentration of minor bioactive constituents were observed among oils from different growing areas, not only between Spanish and Brazilian samples but even within areas of the same country for Arbequina cultivar.

\subsection{Fatty acid composition}

The fatty acid composition is shown in Table 5 . The most representative fatty acids are oleic, linoleic, palmitic, and stearic, which represent $98 \%$ of the composition of total fatty acids. Oleic acid was the most abundant and varied between 64.84 and $80.00 \%$. The large-fruited varieties showed the highest amounts of oleic acid (Sigoise S1: 75\%; Ronde de Miliana Rm: 73.88\%; Rougette de Mitidja (R2: 80.14\%) and lower levels in small-fruit varieties (Chemlal: 67\%), a similar result as reported by Faci et al. (2021) who studied Chemlal of Tizi-Ouzou. These results corroborated with those obtained previously by Douzane (2012) for the same varieties: Sigoise (71.40\%), Ronde de Miliana (80.18\%) and Rougette de Mitidja (74.80\%) collected from Olive production station (Sidi Aich, southern Bejaia). Lower percentages were noted for the Chemlal cultivar produced in several regions (Douzane, 2012). Algerian Chemlal cultivar presents a composition very close to the Tunisian cultivar "Chemlali" which contain low oleic acid and high concentrations of linoleic and palmitic acids (Manai et al., 2007).

Linoleic acid which was the dominant polyunsaturated fatty acid ranged from $6.80 \%$ to $11.70 \%$, while linolenic acid (C18:3) was the minor and ranged from $0.56 \%$ to $0.77 \%$. The levels of linoleic acid are inversely related to oleic acid. According to Sánchez Casas et al. (1999), for better preservation of oils' quality, their linoleic acid content shouldn't be upper than $10 \%$. Lower levels of oxidative stability have been noted in oils containing high proportions of 
linoleic acid (Pardo et al., 2021). Also, Montaño et al. (2016) noted that oxidative stability was clearly correlated positively with oleic acid $(\mathrm{R}=0.688)$ and negatively with linoleic acid $(\mathrm{R}=-0.710)$.

Palmitic acid, the major saturated fatty acids showed an important variation between samples, it ranged from $8.62 \%$ in Rougette de Mitidja cultivar (R2) to $17.57 \%$ in Chemlal cultivar (C5). All samples of Chemlal had high value (superior to $14 \%)$.The other varieties presented an intermediate value (13.24\% for the Ronde de Miliana cultivar (Rm1), between 10.62 and $13.21 \%$ for the Sigoise from different orogins. Statistical analysis revealed a highly significant difference $(\mathrm{P}<0.001)$ between the different samples of a different cultivar.

The values of fatty acids comply with the limits required by the European Commission implementing Regulation (2016/ 1227) and the International Olive Oil Council method (IOC, 2018a) on the characteristics of olive oils.

The percentages of saturated fatty acids (SFA), monounsaturated fatty acids (MUFA), and polyunsaturated fatty acids (PUFA) and the ratios of PUFA/SFA and oleic/ linoleic acids in all samples were also evaluated. It was observed that the oleic acid, the MUFA/ PUFA ratio, and the oleic/ linoleic ratio of the varieties with large medium fruits (Sigoise, Ronde de Miliana, and Rougette de Mitidja) are the highest and are clearly distinguished from the rates of "population cultivar" of small-fruit (Chemlal) (Tab. 5). Some results on the Chemlal cultivar are comparable to those observed by Louadj and Giuffrè (2010); however, our samples were characterized by a broad variation in the mentioned parameters above, due probably to the large geographical origins.

The results obtained in this work showed that the distribution of fatty acids is greatly influenced by olive cultivar. They agree those of others authors (Cicatelli et al., 2013; Fuentes et al., 2015; Cherfaoui et al., 2018). However, many researchers have shown that geographical location has a significant effect. Palmitic acid, oleic acid, linoleic acid, and wax content were found to be significantly affected by the growing region for some cultivars (Rodney et al., 2010). Noorali et al. (2014) noted that the fatty acid profiles could be used to separate olive samples according to their cultivar and growing area, respectively, the fatty acid profile was significantly affected by the growing area for almost all cultivars.

\subsection{Multi dimensional analysis}

The confrontation between the correlations circle of variables and the individual projections (Fig. 2) allowed for determining the characteristics of individuals according to their physicochemical characteristics, with the plane axis. Thus, axis 2 permitted us to distinguish that Chemlal cultivar has been regrouped for highlighting two subgroups, this is caused by the existence of subspecies within Chemlal cultivar to know as Chemlal of Tizi-Ouzou, precocious Chemlal of Tazmalt, Chemlal of Oued-Aissa, and Ali-Sharif's white Chemlal. The most abundant olive cultivar in Algeria, Chemlal, dominated Algerian olive orchards (40\%), probably owing to its unique adaptation to various pedoclimatic conditions (Haddadi and Yakoub-Bougdal, 2010). Chemlal cultivar could be dispersed as a clone.

The medium-fruit cultivar Ronde de Miliana (Rm1) formed a single group, a sign of non-existence of a parental link with other varieties; the same results were noted previously by Douzane (2012). The large-fruited cultivar (Sigoise and Rougette de Mitidja) formed distinct groups. The heterogeneity of Sigoise could be connected to the existence of a mixture within the orchard of producers.

The individual projection allows us to distinguish the different groups (Fig. 2). This structure characterization was made according to the physicochemical analyzes.

Principal component analysis (PCA) allows us to define four groups. The individuals of Group I had the highest values of C18:1 (78.90\%), refractive index (1.4690) as well as the ratios C18:1/C18:2 (11.63) and MUFA/ PUFA (10.63). Besides, they have low C16: 0 (9.69\%), C16: 1 (0.78\%) and $\mathrm{C} 18: 2(6.86 \%)$.

Group II represented by the majority of individuals, was divided into two distinct sub-groups. Subgroup II.1 where its individuals had high humidity values $(0.2 \%)$ and $\mathrm{C} 18: 2$ $(10.14 \%)$, low values of C18:1 $(69,6 \%)$ and polyphenols $(1137.64 \mathrm{mg} / \mathrm{kg})$. Subgroup II.2, the individuals had high values of peroxide index $\left(8.6 \mathrm{meq} \mathrm{O}_{2} / \mathrm{kg}\right), \mathrm{K}_{232}(2.19)$, and $\mathrm{K}_{270}(0.186)$. They are relatively low in C18:1/C18:2 (6.878), C18:1 (68.5\%) and nD20 (1.4682). Group III was represented by individuals that had higher humidity values $(0.23 \%), \mathrm{C} 20: 1$ $(0.31 \%)$, and $\mathrm{C} 18: 3(0.71 \%)$. They presented a low peroxide index $\left(4 \mathrm{meq} \mathrm{O}_{2} / \mathrm{kg}\right), \mathrm{K}_{270}(0.147)$, and $\mathrm{K}_{232}(1.830)$. Ronde de Miliana cultivar (Rm1) formed a separate group (group IV) with high values of C18:0, C18:1 (73.88\%), and an acceptable level of polyphenols $(227.12 \mathrm{mg} / \mathrm{kg})$. It has low values of humidity (0.17), acidity $(0.36 \%)$ and C18:2 (7.46\%).

The concept of quality in olives is complex, and numerous traits might be considered. Different definitions may apply according to the point of view and final goal of producers, traders, consumers, and/or nutritionists. The olive oil composition of cultivar results from a very complex multivariate interaction between the genotypic potential and the environmental, agronomic, and technological factors that characterize fruit growth and ripening as well as oil extraction and storage (Lavee and Wodner, 1991). Some olive varieties like Chemlal are diffused as a clone. No genetic variation exists, therefore between the individuals. All variations in the final product are consequently attributable to environmental and physical factors. The mechanisms underlying environmentally-caused variations in oil composition are for the most part unknown. The results of previous studies (Ben Temime et al., 2006; Borges et al., 2017) have highlighted the effect of cultivar-environment interaction in the expression of the quality of olive oil. The changes in oil composition of the Tunisian Chetoui cultivar according to the plantation origin were studied (Ben Temime et al., 2006). The results showed considerable variability in oil composition. The characteristics of the EVOO Arbequina from Brazil in comparison with Spanish Arbequina from different regions were recently studied (Borges et al., 2017). The findings reveal that geographic and climate aspects of producing areas may significantly influence the quality and composition of Arbequina olive oil. 
M. Douzane et al.: OCL 2021, 28, 55

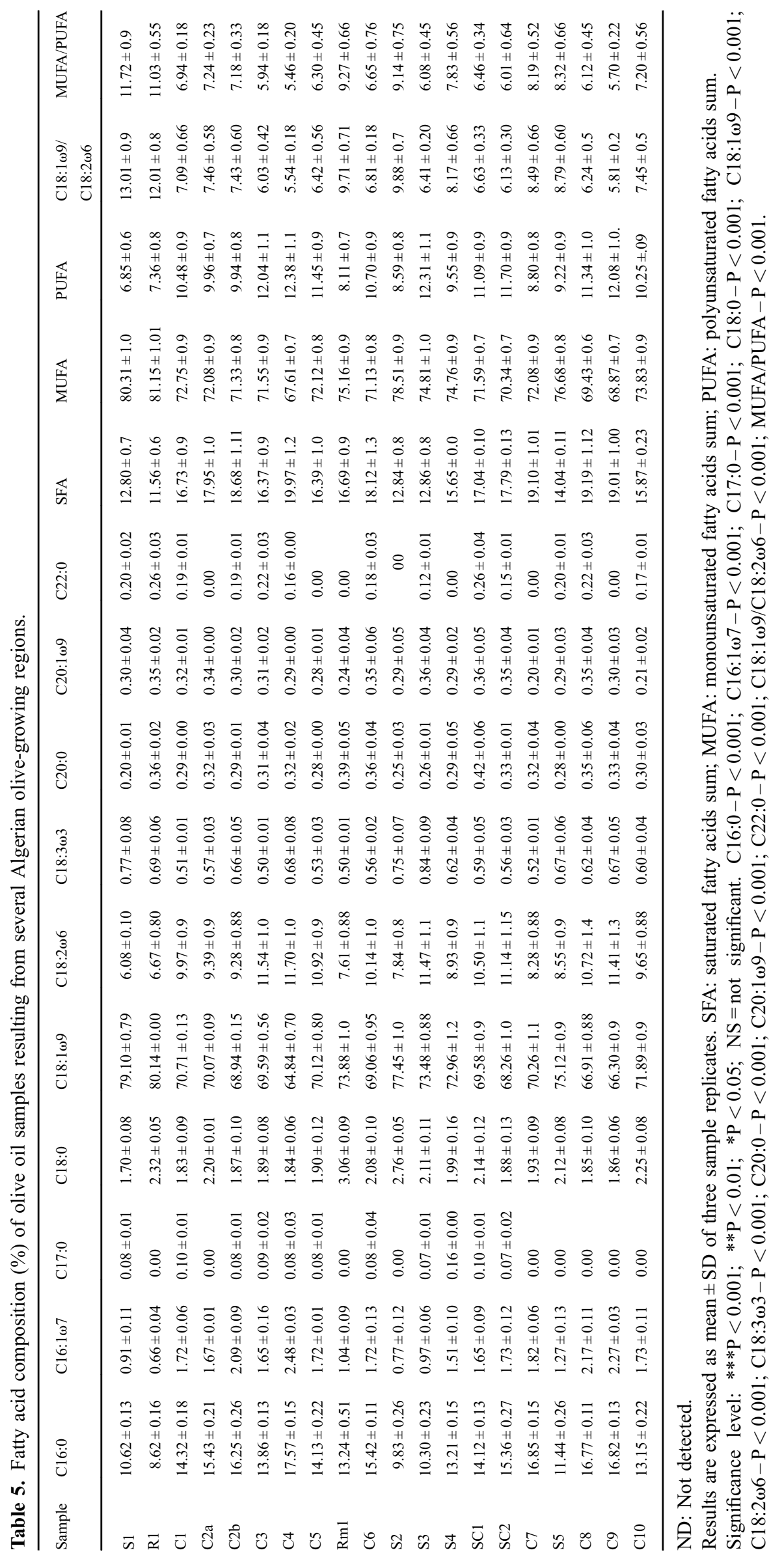

Page 9 of 11 


\section{Conclusion}

The results showed that the cultivar plays an important role in the qualitative characteristics and sensory attributes of olive oils. The oil of Rougette de Mitidja cultivar from Mitidja (R1) showed the best sensory and physicochemical results. It also exhibited the best levels of oleic acid, qualifying it as the best extra virgin olive oil in Algeria for the 2018/2019 olive season. Ronde de Miliana (Rm1) also showed great potential.

Many other olive cultivars are unexplored in terms of quality traits, more effort should be made to assess them. On the other hand, olive growers must be encouraged to promote the local olive-growing heritage by cultivating varieties approved by the National Center for seeds and plants Control and Certification (CNCC).

Acknowledgements. The authors are grateful to the private olive growers for the plant material used in the experiments.

Conflicts of interest. The authors declare that they have no conflicts of interest in relation to this article.

\section{References}

Al-Ruqaie I, Al-Khalifah NS, Shanavaskhan AE. 2016. Morphological cladistic analysis of eight popular Olive (Olea europaea L.) cultivars grown in Saudi Arabia using Numerical Taxonomic System for personal computer to detect phyletic relationship and their proximate fruit composition. Saudi J Biol Sci 23(1): 115-21.

Angerosa F. 2002. Influence of volatile compounds on virgin olive oil quality evaluated by analytical approaches and sensor panels. Eur J Lipid Sci Technol 104: 639-660.

Angerosa F, Servili M, Selvaggini R, Taticchi A, Esposto S, Montedoro G. 2004. Volatile compounds in virgin olive oil: occurrence and their relationship with the quality. JChromatogr $A$ 1054: 17-31.

Arslan D, Karabekir Y, Schreiner M. 2013. Variations of phenolic compounds, fatty acids and some qualitative characteristics of Sartulak olive oil as induced by growing area. Food Res Int 54: 1897-1906.

Bedbabis S, Clodoveo ML, Rouina BB, Boukhris M. 2010. Influence of irrigation with moderate saline water on "chemlali" extra virgin olive oil composition and quality. J Food Qual 33: 228-47.

Ben Rached M, Galaverna G, Cirlini M, Boujneh D, Zarrouk M, Guerfel M. 2017. Pedologic factors affecting virgin olive oil quality of "Chemlali" olive trees (Olea europaea L.). J Oleo Sci 66(8): 907-915.

Ben Temime S, Taamalli W, Bacccouri B, Abaza L, Daoud D, Zarrouk M. 2006. Changes in olive oil quality of Chétoui variety according to origin of plantation. J Food Lipids 13: 88-99.

Bendini A, Cerretani L, Carrasco-Pancorbo A, et al. 2007. Phenolic molecules in virgin olive oils: A survey of their sensory properties, health effects, antioxidant activity and analytical methods. An overview of the last decade. Molecules 12: 1679-1719.

Benlemlih M, Ghanam J. 2016. Polyphenols d'huile d'olive. Trésors santé, $2^{\mathrm{e}}$ éd. Ed: Medicatrix, $208 \mathrm{p}$.

Borges TH, Pereira JA, Cabrera-Vique C, Lara L, Oliveira AF, Seiquer, I. 2017. Characterization of Arbequina virgin olive oils produced in different regions of Brazil and Spain: Physicochemical properties, oxidative stability and fatty acid profile. Food Chem 215: 454-462.
Caporale GM, Pittis N, Spagnolo N. 2006. Volatility transmission and financial crises. J Econ Finance 30 (3): 376-90.

Cherfaoui M, Cecchi T, Keciri S, Boudriche L. 2018. Volatile compounds of Algerian extra-virgin olive oils: Effects of cultivar and ripening stage. Int J Food Prop 21: 36-49.

Cicatelli A, Fortunati T, De Feis I, Castiglione S. 2013. Oil composition and genetic biodiversity of ancient and new olive (Olea europaea L.) varieties and accessions of southern Italy. Plant Sci 210: 82-92.

Codex Alimentarius. 2017. Norme pour les huiles d'olive vierges et huiles de grignons d'olive, Codex STAN 33-1981 (Rév. 2017).

Conte L, Bendini A, Valli E, et al. 2020. Olive oil quality and authenticity: A review of current EU legislation, standards, relevant methods of analyses, their drawbacks and recommendations for the future. Trends Food Sci Technol 105: 483-493.

Del Caro A, Vacca V, Poiana M, Fenu P, Piga A. 2006. Influence of technology, storage and exposure on components of extra virgin olive oil (Bosana $\mathrm{cv}$ ) from whole and de-stoned fruits. Food Chem 98: 311-316.

Douzane M. 2012. Recherche de composés biochimiques de l'huile d'olive, utilisés comme marqueurs d'identification de variétés locales d'oliviers. Thèse de Doctorat en Sciences Agronomiques, ENSA, El Harrach, 220 p.

Douzane M, Tamendjari A, Abdi AK, Daas MS, Mehdid F, Bellal MM. 2013. Phenolic compounds in mono-cultivar extra virgin olive oils from Algeria. Grasas Aceites 64: 285-294.

El Riachy M, Bou-Mitri C, Youssef A, Andary R, Skaff W. 2018. Chemical and sensorial characteristics of olive oil produced from the Lebanese olive variety "Baladi". Sustainability 10: 4630.

European Commission. 2015. European Commission implementing Regulation 2015/1833 amending Regulation (EEC) No. 2568/91 on the characteristics of olive oil and olive-residue oil and on the relevant methods of analysis. Official Journal of the European Union 2015(October 12, L.266): 29-52.

European Commission. 2016. European Commission implementing Regulation 2016/1227 amending Regulation (EEC) No. 2568/91 on the characteristics of olive oil and olive-residue oil and on the relevant methods of analysis. Official Journal of the European Union 2016(July 27, L.202): 7-13.

Faci M, Hedjal M, Douzane M, Sevim D, Köseoglu O, Tamendjari A. 2021. Locations Effects on the Quality of Chemlal and Azeradj Olives Grown in Algeria. J Am Oil Chem Soc 98 (5): 551-566.

FAOSTAT. 2018. Food and Agriculture Organization of the United Nations Statistical Dataset. Rome, Italy: FAO.

Fernandes GD, Ellis AC, Gámbaro A, Barrera-Arellano D. 2018. Sensory evaluation of high-quality virgin olive oil: Panel analysis versus consumer perception. Curr Opin Food Sci 21: 66-71.

Fuentes M, De Miguel C, Ranalli A, Francoa MN, Martinez M, Martin-Vertedora D. 2015. Chemical composition and sensory evaluation of virgin olive oils from "Morisca" and "Carrasquena" olive varieties. Grasas Aceites 66: 1-16.

Gharbi I, Issaoui M, Mehri S, Cheraief I, Sifi S, Hammami, M. 2015. Agronomic and technological factors affecting Tunisian olive oil quality. Agric Sci 6: 513-526.

Giuffrè AM. 2017. Biometric evaluation of twelve olive cultivars under rainfed conditions in the region of Calabria, South Italy. Emir J Food Agric 29: 696-709.

Gutfinger T. 1981. Polyphenols in olive oil. J Am Oil Chem Soc 58: 966-968.

Haddadi M, Yakoub-Bougdal S. 2010. Olive rootstock production from Olea europea Var. Chemlal Cultured in Vitro. Cah Agric 19: 288-291. 
International Olive Oil Council (IOC). 2015a. Document COI/T.20/ Doc. No.34. Détermination des acides gras libres, méthode à froid. Madrid: International Olive Oil Council.

International Olive Oil Council (IOC). 2015b. Document COI/T.20/ Doc. No.19/Rev.3. Spectrophotometer investigation in the ultraviolet. Madrid: International Olive Oil Council.

International Olive Oil Council (IOC). 2016. Document COI/T.20/ Doc. No. Determination of peroxide value. Madrid: International Olive Oil Council.

International Olive Oil Council (IOC). 2018a. Trade standard applying to olive oils and olive pomace oils. IOC/T.15/NC No.3/Rev.12, pp. 1-17.

International Olive Council (IOC). 2018b. Mario Solinas quality award rules of the international competition for extra virgin olive oils. T.30/Doc. No.21 March 2018, pp. 1-9.

International Olive Oil Council (IOC). 2018c. Sensory analysis of olive oil method for the organoleptic assessment of virgin olive oil. T.20/Doc. No.15/Rév.10.

International Organization for Standardization (ISO). 2006. Animal and vegetable fats and oils. Determination of refractive index 6320:2000.

International Organization for Standardization (ISO) 662/2016. 2016. Graisses et huiles animales et végétales. Détermination de la teneur en eau et matières volatils.

International Union of Pure and Applied Chemistry (IUPAC). 1987. Commission on oils, fats and derivatives: Standard methods for the analysis of oils, fats and derivatives/C. Paquot et A. Hautfenne. Edition. $7^{\mathrm{e}}$ ed. Oxford, London, Edinburgh, Boston. Palo Alto, Black-Well Scientific Puplication, Methode 2.101; 2.102, 2.2.02, 2.4.01, 2.501.

Lavee S, Wodner M. 1991. Factors affecting the nature of oil accumulation in fruit of olive (Olea europaea L.) cultivars. $J$ Hortic Sci Biotechnol 66: 583-591.

Lou-Bonafonte JM, Arnal C, Navarro MA, Osada J. 2012. Efficacy of bioactive compounds from extra virgin olive oil to modulate atherosclerosis development. Nutr Food Res 56: 1043-1057.

Louadj L, Giuffrè AM. 2010. Analytical characteristics of olive oil produced with three different processes in Algeria. Riv Ital Sostanze Grasse 87(3): 187-195.

Manai H, Mahjoub-Haddada F, Trigui A, Daoud D, Zarrouk M. 2007. Compositional quality of virgin olive oil from two new Tunisian cultivars obtained through controlled crossings on Chemlali variety. J Sci Food Agric 87(4): 600-606.

Mele MA, Islam MZ, Kang HM, Giuffrè AM. 2018. Pre-and postharvest factors and their impact on oil composition and quality of olive fruit. Emir J Food Agric 30(7): 592-603.

Ministry for Agriculture and the rural development (M.A.D.R). 2010. Agricultural Statistics Series B, 49 p.
Ministry for Agriculture the Rural Development and Peach (M.A.D. R.P). 2018. Agricultural Statistics Series B.

Montaño A, Hernández M, Garrido I, Llerena JL, Espinosa F. 2016. Fatty Acid and phenolic compound concentrations in eight different monovarietal virgin olive oils from Extremadura and the relationship with oxidative stability. Int J Mol Sci 17(11): 1960.

Navas-López JF, Cano J, de la Rosa R, Velasco L, León L. 2020. Genotype by environment interaction for oil quality components in olive tree. Eur J Agron 119: 126115.

Noorali M, Barzegar M, Sahari MA. 2014. Sterol and fatty acid compositions of olive oil as an indicator of cultivar and growing area. J Am Oil Chem Soc 91: 1571-1581.

Pardo JE, Rabadán A, Suárez M, Tello J, Zied DC, Álvarez-Ortí M. 2021. Influence of olive maturity and season on the quality of virgin olive oils from the area assigned to the protected designation of origin of "Aceite de la Alcarria" (Spain). Agronomy 11: 1439.

Piscopo A, De Bruno A, Zappia A, Ventre C, Poiana M. 2016. Characterization of monovarietal olive oils obtained from mills of Calabria region (Southern Italy). Food Chem 213: 313-318.

Rallo L, Díez CM, Morales-Sillero A, Miho H, Priego-Capote F, Rallo, P. 2018. Quality of olives: A focus on agricultural proharvest factors. Sci Hortic 233: 491-509.

Rodney JM, Ayton J, Graham K. 2010. The influence of growing region, cultivar and harvest timing on the diversity of Australian olive oil. J Am Oil Chem Soc 87: 877-884.

Rotondi A, Bendini A, Cerretani L, Mari M, Lercker G, GallinaToschi T. 2004. Effect of olive ripening degree on the oxidative stability and organoleptic properties of cv. Nostrana di Brisighella Extra Virgin Olive Oil. J Agric Food Chem 52: 3649-3654.

Sánchez Casas J, De Miguel Gordillo C, Marín Exposito J. 1999. La qualité de l'huile d'olive provenant de variétés cultivées en Estrémadure en fonction de la maturation de l'olive. Olivae 75: 31-36.

Škevin D, Rade D, Strucelj D, Mokrovcak Z, Nederal S, 2003. The influence of variety and harvest time on the bitterness and phenolic compounds of olive oil. Eur J Lipid Sci Technol 105(9): 536-541.

Tura D, Failla O, Bassi D, Pedo S, Serraiocco A. 2008. Cultivar influence on virgin olive (Olea europea L.) oil flavor based on aromatic compounds and sensorial profile. Sci Hortic 118: 139148.

Visioli F, Galli C. 1998. Olive oil phenols and their potential effects on human health. Agric Food Chem 46: 4292-6.

Visioli F, Franco M, Toledo E, et al. 2018. Olive oil and prevention of chronic diseases: Summary of an international conference. Nutr Metab Cardiovasc Dis 28(7): 649-656.

Cite this article as: Douzane M, Daas M-S, Meribai A, Guezil A-H, Abdi A, Tamendjari A. 2021. Physico-chemical and sensory evaluation of virgin olive oils from several Algerian olive-growing regions. OCL 28: 55. 